\title{
Formation of Organizational Competence of Future Engineers By Means of Blended Learning
}

\author{
https://doi.org/10.3991/ijep.v10i2.12047 \\ Lyudmila A. Obukhova $(\bowtie)$ \\ Voronezh State University, Voronezh, Russia \\ lyudmila.obukhova@rambler.ru \\ Olga V. Galustyan \\ Southern Federal University, Rostov-on-Don, Russia \\ Igor O. Baklanov, Roman V. Belyaev, Lyubov A. Kolosova \\ The Military Educational and Scientific Center of "The Air Force Academy named after \\ Zhukovsky N.E. and Gagarin Y.A.”, Voronezh, Russia \\ Tatyana V. Dubovitskaya \\ Voronezh State Technical University, Voronezh, Russia
}

\begin{abstract}
The article outlines the need of formation of organizational competence of future engineers by means of blended learning. Blended learning contributes to the organizational competence of future engineers using high educational potentials of digital resources. Blended learning allows to implement modern teaching concepts due to its accessibility, easiness of usage, socialization, possibility of organizing collaborative activities and evaluating methods. The authors conclude that use of blended learning can significantly increase the effectiveness of educational process and quality of student' training.
\end{abstract}

Keywords - Organizational competence, blended learning, teaching tools, ICT tools, future engineers.

\section{Introduction}

One of the most important features of the modern world are transformations in economy, politics, society, which entail changes in the educational sphere. The updated system of society dictates new requirements for individuals as members of society for their educational and professional training especially in engineering sphere as the basis of modern economy. Therefore, engineering educational institutions should improve their activities aimed at developing the effectiveness of engineering education within the new conditions $[5,9,10]$.

The problem of formation and development of organizational competence of future engineers has been within the focus of attention of scientific community for a long 
time. It has gained importance in the recent decades. This happens because global changes, which are taking place in the world, have increased the requirements for the engineers. Modern society needs engineers who are able to unite, to lead and to solve the tasks successfully. These circumstances dictate new requirements, including those where special emphasis is done on independence, self-organization, self-control, selfreflection, and self-development of future engineers [3, 11, 18].

Modernization of engineering education is determined by the need to improve the quality of training, which means comprehensive development of engineers, including breadth and flexibility of training, desire of creativity and ability to solve nonstandard tasks, critical reflection of necessary information, continuous selfimprovement and awareness of personal responsibility for the results.

Formation of organizational competence of future engineers is of tremendous importance in their personal and professional development [22, 24, 27]. In our opinion, it is impossible to ensure the effectiveness of educational process, and, as a result, quality of professional training without the formation of organizational competence of future engineers.

Authors [7, 13], who examine the problems of formation of organizational competence of future engineers, consider that application of information and communication technologies within the practice of higher education allows to carry out this process more efficiently.

Growth of information determines the content of engineering education. One of the factors which leads to increase of the quality of engineering education is educational environment of university, an important part of which is educational information environment. Currently, many informational resources are being developed. Most of the educational, scientific and methodological materials, which are used within the educational practice, have been transferred into digital form [4, 20, 26]. Educational tools are created considering capabilities and advantages of computer technologies. They contribute to the further development of new forms of educational activity.

$[17,19,21]$ consider blended learning as an effective approach for the formation of organizational competence of future engineers within the context of informatization of the educational sector. Blended learning is becoming an important link of engineering educational system of professional training of future engineers at the present stage.

\section{Methodology}

Modern engineering educational process is characterized by the development of the latest computer technologies, and, consequently, by the development of new teaching technologies, one of which is blended learning. This technology of organization of educational process combines with the advantages of traditional contact education and distance learning as well. Blended learning makes it possible to build individual trajectories for students in order to learn educational materials, to develop their educational actions, and to ensure stable activity of students. It is based on theories of social constructivism and problem-based education which are recognized in the world pedagogical community $[2,8]$. 
It is necessary to create and to use the latest ICT tools in training, such as electronic encyclopedias, tests, questionnaires, etc. Information and communication technologies (ICT) is a set of methods, software and hardware integrated with the aim of collecting, processing, storage, distribution, display and use of information. Blended learning is developing rapidly due to the development of the Internet, modern methods of communication and exchange of materials and data. A lot of universities introduce blended learning into the educational process, and it is being applied at the fastest rate in the field of large business in organizing corporate training. Today it becomes possible and relevant to apply theoretical and practical developments in the field of blended learning to solve the problem of organizational competence of future engineers as well.

$[1,12]$ consider that blended learning is teaching system which includes full-time, distance education and self-study, interaction between teachers and students, use of interactive sources of information. Blended learning reflects all the components of the educational process such as aim, content, methods, organizational forms, teaching aids which are functioning in the constant interaction with each other.

The benefits of blended learning are the following:

- Teacher is available at any time

- Training is organized at any time and place

- Individual evaluation is done

- Content is available for frequent use

- A lot of didactic approaches are available [15, 28].

Blended learning is a modern approach of organization of educational environment, which includes face-to-face work of teacher and students and online learning using ICT. It is important to note that traditional education and e-learning are used within this type of educational process. Self-regulated learning and collaborative learning, face-to-face and distance learning are blended within this educational approach.

$[6,29]$ distinguish three components of blended learning:

- Direct training with personal contact of teacher and students in the form of traditional classroom lessons

- Self-regulated learning of students, which includes various types of activities (search tasks using Internet, web-quests, etc.) without the assistance of a teacher

- Collaborative e-learning which consists of implementation of various digital tasks, participating in webinars, online conferences, wikis, etc.

Blended learning is a method that combines elements of both traditional and innovative learning. One of the most important components of innovative learning is distance learning, which gives opportunity to highlight advantages application of ICT tools.

Researchers [14, 25] consider that distance learning will replace traditional engineering educational system, since distance learning accelerates the process of obtaining knowledge. However, participants of the educational process, both teachers 
and students, are not ready to refuse from face-to-face communication and knowledge transfer, as it develops social and cultural skills. Traditional learning is distinguished by the interaction both between teacher and students, and students between each other. Face-to-face education allows to share knowledge with the others, to get necessary information and to communicate.

One of the most important advantages of blended learning is the ability of a teacher to present training material in various forms. It should be noted that blended learning allows students to reveal their individual abilities, to absorb information at their own pace. Modern generation of young people is in a constant flow of information now. Blended learning makes it possible to motivate them to receive information in a nonstandard form and to perform non-traditional tasks. According to [16, 23], the process of blended learning is perceived by the participants of educational process as something exciting, interesting and not requiring uniform, monotonous work from its participants. Blended learning is created in order to teach students to formulate questions and to answer them, to solve educational problems in a variety of ways, to work in an information environment. Moreover, blended learning is characterized by certain methods, techniques, models and principles of training. Their implementation is impossible without clearly defined methodology of presentation of material, design, in order to reveal the full potential of blended learning.

\section{$3 \quad$ Materials and Methods}

We conducted our experiment at Voronezh State Technical University and Military Educational and Scientific Center of "The Air Force Academy named after Zhukovsky N.E. and Gagarin Y.A.", Voronezh) within the training courses on the development of organizational competence in 2018-2019. 215 students and cadets of specialty "Electrical Engineering" participated in the experimental work. Age of the participants of the experimental work was from 20 to 22 years. There were 107 participants in the experimental group. The control group consisted of 108 participants. Students and cadets of control group were trained within the traditional face-to-face educational system.

Formation of the organizational competence of future engineers by means of blended learning in the experimental group included:

- Self-regulated learning

- Organization of individual support by the teacher for educational activities of each student based on the use of online communication technologies

- Group training activities, including collaborative work on projects, discussions, seminars in the form of digital teleconferences, forums, which were organized synchronous and asynchronous in time.

We used both traditional and innovative teaching methods within the process of teaching of the course "Modern Information and Communication Technologies in Blended Learning". It allowed to ensure high quality and systematic learning. It also 
enabled students of experimental group to obtain new knowledge, skills and competencies, including ability to learn independently.

Teacher organized work with the students directly in the classroom and with the students remotely using modern information and communication technologies (Skype, Viber, WhatsApp) and the capabilities of Internet.

At the beginning each lesson, the teacher updated material using the "heuristic method of questions". The essence of this method was to find answers to seven key questions: "Who?", "What?", "Why?", "Where?", "What?", "How?", "When?". The answer to these questions of each member of the group and a brief discussion generated unusual ideas and solutions of the problems.

All the students were divided into work groups regardless of their actual presence in the audience, since this organization of work was based on using web-technologies. It helped students to participate in the discussion and consolidation of material actively. Then teacher organized web-discussion, which revitalized learning process of the audience. It allowed the teacher to direct collective opinion of the group, to overcome negative attitudes and incorrect opinions. The effect was achieved with the correct selection of questions by teacher for discussion and experienced and purposeful management of discussion. Teacher also organized exchange of information between two groups of students who have opposing opinions.

Final stage of the work was to consolidate the material in practice. Teacher offered students to get acquainted with modern ICT, using digital resources, digital libraries, databases, multimedia files.

\section{$4 \quad$ Results}

The purpose of the initial stage of the experiment was to determine the initial level. Organizational competence includes ability of self-determination, setting goals, choosing appropriate means of achieve it, making decisions independently, organization and carrying out professional activities, reflection of one's own activities and activities of all participants of professional process; ability of solving emerging professional problems, willingness and ability of choosing effective methods of action, strategies of behavior in particular situations of professional activity.

We have identified analytical, communicative, social, and monitoring components within the structure of organizational competence. Analytical component is expressed in the analysis of professional activities, development of methods (techniques) and tools for identifying the effectiveness of forecasting professional activities. Communicative component is expressed in the ability and readiness for social perception in personal and business communication; ability to express one's point of view; ability to prevent and to resolve conflict situations. Social component is ability and willingness to carry out collaborative professional activities, willingness and ability to collaborate with the others and to be responsible for the results of work. Monitoring component is ability and willingness of carry out systematic monitoring of state and effectiveness of work, of one's own professional and personal 
development, willingness and ability of carrying out planning, updating and forecasting one's work.

The practical implementation of the research process of was carried out in the form of an analysis based on Likert scale. The results of the study are presented in Table 1 and Table 2.

Table 1. Level of organizational competence in the experimental and control groups at the beginning of the experiment

\begin{tabular}{|l|c|c|c|c|c|c|}
\hline \multirow{2}{*}{ Organizational competence } & \multicolumn{3}{|c|}{ Experimental group } & \multicolumn{3}{c|}{ Control group } \\
\cline { 2 - 7 } & $\begin{array}{c}\text { Low level, } \\
\boldsymbol{\%}\end{array}$ & $\begin{array}{c}\text { Middle level, } \\
\boldsymbol{\%}\end{array}$ & $\begin{array}{c}\text { High level, } \\
\boldsymbol{\%}\end{array}$ & $\begin{array}{c}\text { Low level, } \\
\boldsymbol{\%}\end{array}$ & $\begin{array}{c}\text { Middle level, } \\
\%\end{array}$ & $\begin{array}{c}\text { High level, } \\
\boldsymbol{\%}\end{array}$ \\
\hline Analytical component & 40,5 & 38,1 & 21,4 & 39,7 & 38,8 & 21,5 \\
\hline Communicative component & 55,2 & 28,6 & 16,2 & 37,4 & 39,3 & 23,3 \\
\hline Social component & 42,8 & 33,6 & 23,6 & 41,2 & 30,4 & 28,4 \\
\hline Monitoring component & 56,1 & 29,4 & 14,5 & 43,8 & 34,6 & 21,6 \\
\hline
\end{tabular}

Table 2. Level of organizational competence in the experimental and control groups at the end of the experiment

\begin{tabular}{|l|c|c|c|c|c|c|}
\hline \multirow{2}{*}{ Organizational competence } & \multicolumn{3}{|c|}{ Experimental group } & \multicolumn{3}{c|}{ Control group } \\
\cline { 2 - 7 } & $\begin{array}{c}\text { Low level, } \\
\boldsymbol{\%}\end{array}$ & $\begin{array}{c}\text { Middle level, } \\
\mathbf{\%}\end{array}$ & $\begin{array}{c}\text { High level, } \\
\mathbf{\%}\end{array}$ & $\begin{array}{c}\text { Low level, } \\
\mathbf{\%}\end{array}$ & $\begin{array}{c}\text { Middle level, } \\
\%\end{array}$ & $\begin{array}{c}\text { High level, } \\
\text { \% }\end{array}$ \\
\hline Analytical component & 12,4 & 37,3 & 50,3 & 41,7 & 38,5 & 19,8 \\
\hline Communicative component & 8,3 & 26,7 & 65,0 & 34,2 & 43,5 & 22,3 \\
\hline Social component & 8,3 & 23,1 & 68,6 & 32,8 & 37,9 & 29,3 \\
\hline Monitoring component & 5,7 & 27,6 & 66,7 & 42,1 & 36,1 & 21,8 \\
\hline
\end{tabular}

The results of experimental work on the implementation of blended learning of the formation of organizational competence in control and experimental groups revealed that in the experimental group the level of organizational competence is higher than in the control group, that proves the effectiveness of experimental work.

\section{Conclusion}

Summing up, it should be noted that formation of organizational competence of future engineers is a deep process which works within blended learning, allowing students to develop and to improve their educational results. Blended learning allows to form organizational competence of future engineers with the appropriate teacher's supervision. Blended learning provides excellent intellectual and technical environment in which development of necessary skills are possible in the modern information society. 


\section{$6 \quad$ References}

[1] Aguilar-Rodríguez, M., Marques-Sule, E., Serra-Añó, P., Espí-López, G. V., DueñasMoscardó, L., \& Pérez-Alenda, S. (2019). A blended learning programme regarding professional ethics in physiotherapy students. Nursing Ethics, 26(5), 14101423.https://doi.org/10.1177/0969733017748479

[2] Ahmed, A. A. (2017). Perception of blended learning approaches in higher educator sector: Critical review and proposed learning model for imam kadhim college for islamic science university. Turkish Online Journal of Educational Technology, 2017(December Special Issue ITEC), 990-1003.

[3] Antropova, L. I., Kazikin, A. V., \& Lesher, O. V. (2019). Formation of the communicative creativity of academy students: Organizational and conceptual component. [Формирование коммуникативной креативности студентов вуза: организационносодержательный компонент] Perspektivy Nauki i Obrazovania, 39(3), 119-132. https://doi.org/10.32744/pse.2019.3.9

[4] Bosman, L. B., Duval-Couetil, N., Mayer, B., \& McNamara, P. (2019). Using online discussions to develop the entrepreneurial mindset in environmental engineering undergraduates: A case study. International Journal of Engineering Pedagogy, 9(3), 4-19. https://doi.org/10.3991/ijep.v9i3.9491

[5] Bubnov, Y. A., Gaidar, K. M., Fedorov, V. A., Berezhnaya, I. F., \& Galustyan, O. V. (2018). Organization of the training process based on modular and rating technology at higher educational institution. Espacios, 39(25)

[6] Cocquyt, C., Zhu, C., Diep, A. N., De Greef, M., \& Vanwing, T. (2019). Examining the role of learning support in blended learning for adults' social inclusion and social capital. Computers and Education, $142 \mathrm{https}$ ://doi.org/10.1016/j.compedu.2019.103610

[7] Froissard, J., Liu, D., Richards, D., \& Atif, A. (2019). A learning analytics pilot in moodle and its impact on developing organisational capacity in a university. Paper presented at the ASCILITE 2017 - Conference Proceedings - 34th International Conference of Innovation, Practice and Research in the use of Educational Technologies in Tertiary Education, 73-77.

[8] Galustyan, O. V., Borovikova, Y. V., Polivaeva, N. P., Kodirov, B. R., \& Zhirkova, G. P. (2019). E-learning within the field of andragogy. International Journal of Emerging Technologies in Learning, 14(9), 148-156. https://doi.org/10.3991/ijet.v14i09.10020

[9] Galustyan, O. V., Gaidar, K. M., Aleshina, S. A., Ksenofontova, A. N., \& Ledeneva, A. V. (2018). Development of group subjectivity of pupils within collaborative activities. TEM Journal, 7(4), 854-858. doi:10.18421/TEM74-25

[10] Galustyan, O. V., Lazukin, V. F., Petelin, A. S., \& Ostapenko, V. S. (2018). Diagnostic Activity of Teachers at High School. Revista Espacios, Vol. 39(N 10). Retrieved from http http://www.revistaespacios.com/a18v39n10/18391024.html

[11] Galustyan, O. V., Meshcheryakova, E. I., Larina, T. V., Bakleneva, S. A., \& Krivotulova, E. V. (2018). Self-regulated learning of students at university. Espacios, 39(23)

[12] Geng, S., Law, K. M. Y., \& Niu, B. (2019). Investigating self-directed learning and technology readiness in blending learning environment. International Journal of Educational Technology in Higher Education, 16(1) https://doi.org/10.1186/s41239-019$\underline{0147-0}$

[13] Huang, Y., Yan, A., \& Smith, R. (2019). Methodology for the development of knowledge management on organizational performance based on employees' professional competence. Revista De Cercetare Si Interventie Sociala, 64, 85-96. https://doi.org/10.3 $\underline{3788 / \text { rcis. } 64.7}$ 
[14] Hui, Y. K., Li, C., Qian, S., \& Kwok, L. F. (2019). Learning engagement via promoting situational interest in a blended learning environment. Journal of Computing in Higher Education, 31(2), 408-425. https://doi.org/10.1007/s12528-019-09216-Z

[15] Ibrahim, M. M., \& Nat, M. (2019). Blended learning motivation model for instructors in higher education institutions. International Journal of Educational Technology in Higher Education, 16(1) https://doi.org/10.1186/s41239-019-0145-2

[16] Kadek Suartama, I., Setyosari, P., Sulthoni, \& Ulfa, S. (2019). Development of an instructional design model for mobile blended learning in higher education. International Journal of Emerging Technologies in Learning, 14(16), 4-22. https://doi.org/10.399 $\underline{1 / \text { ijet.v14i16.10633 }}$

[17] Koraneekij, P., \& Khlaisang, J. (2019). Students' beliefs regarding the use of e-portfolio to enhance cognitive skills in a blended learning environment. International Journal of Emerging Technologies in Learning, 14(2), 85-104. https://doi.org/10.39 91/ijet.v14i02.8288

[18] Kravchenko E.V., Galustyan O.V, Kovtunenko L.V., \& Kolosova L.A. (2018). Pedagogical Practice of Students. Revista Espacios, Vol. 39 (N 17). Retrieved from http://www.revistaespacios.com/a18v39n17/18391731.html

[19] Lazem, S. (2019). On designing blended learning environments for resource-challenged communities. International Journal of Emerging Technologies in Learning, 14(12), 183192. https://doi.org/10.3991/ijet.v14i12.10320

[20] Martin, D. A. (2018). Shaping the digital future in education - together. International Journal of Engineering Pedagogy, 8(2), 7-9. https://doi.org/10.3991/ijep.v8i2.8228

[21] Mills, D., \& James, D. (2019). Reconceptualising organisational collaborations in social science doctoral education. Higher Education, https://doi.org/10.1007/s10734-019-00438-9

[22] Mingaleva, Z., Deputatova, L., \& Starkov, Y. (2020). Management of organizational knowledge as a basis for the competitiveness of enterprises in the digital economy https://doi.org/10.1007/978-3-030-22493-6_18

[23] Musabirov, I., Pozdniakov, S., \& Tenisheva, K. (2019). Predictors of academic achievement in blended learning: The case of data science minor. International Journal of Emerging Technologies in Learning, 14(5), 64-74. https://doi.org/10.3991/ijet.v14i05.9512

[24] Palacios-Marqués, D., García, M. G., Sánchez, M. M., \& Mari, M. P. A. (2019). Social entrepreneurship and organizational performance: A study of the mediating role of distinctive competencies in marketing. Journal of Business Research, 101, 426-432. https://doi.org/10.1016/j.jbusres.2019.02.004

[25] Rienties, B., Tempelaar, D., Nguyen, Q., \& Littlejohn, A. (2019). Unpacking the intertemporal impact of self-regulation in a blended mathematics environment. Computers in Human Behavior, 100, 345-357. https://doi.org/10.1016/j.chb.2019.07.007

[26] Vorbach, S., Maria Poandl, E., \& Korajman, I. (2019). Digital entrepreneurship education: The role of MOOCs. International Journal of Engineering Pedagogy, 9(3), 99-111. https://doi.org/10.3991/ijep.v9i3.10149

[27] Wahyuni, S., Gusti Made Sanjaya, I., Erman, \& Jatmiko, B. (2019). Edmodo-based blended learning model as an alternative of science learning to motivate and improve junior high school students' scientific critical thinking skills. International Journal of Emerging Technologies in Learning, 14(7), 98-110. https://doi.org/10.39 91/ijet.v14i07.9980

[28] Wang, R. (2019). Massive open online course platform blended English teaching method based on model-view-controller framework. International Journal of Emerging Technologies in Learning, 14(16), 188-196. https://doi.org/10.3991/ijet.v14i16.11151 
[29] Yu, W., \& Du, X. (2019). Implementation of a blended learning model in content- based EFL curriculum. International Journal of Emerging Technologies in Learning, 14(5), 188199. https://doi.org/10.3991/ijet.v14i05.8546

\section{$7 \quad$ Authors}

Lyudmila A. Obukhova is Professor, Head of Research Center of Voronezh Institute for Educational Development, Voronezh, Russia. Email: lyudmila.obukhova@ rambler.ru

Olga V. Galustyan is Professor of the Department of Education and Pedagogical Sciences of Southern Federal University, Rostov-on-Don, Russia.

Igor O. Baklanov is Professor, Head of the Department of Physics and Chemistry, of The Military Educational and Scientific Center of "The Air Force Academy named after Zhukovsky N.E. and Gagarin Y.A.”, Voronezh, Russia.

Roman V. Belyaev is Head of Research Center of Educational and Information Technologies of The Military Educational and Scientific Center of "The Air Force Academy named after Zhukovsky N.E. and Gagarin Y.A.”, Voronezh, Russia.

Lyubov A. Kolosova is Professor, Senior Researcher of Research Center of Educational and Information Technologies of The Military Educational and Scientific Center of "The Air Force Academy named after Zhukovsky N.E. and Gagarin Y.A.", Voronezh, Russia.

Tatyana V. Dubovitskaya is Associate Professor of Department of Physics of Voronezh State Technical University, Voronezh, Russia.

Article submitted 2019-10-27. Resubmitted 2020-01-02. Final acceptance 2020-01-03. Final version published as submitted by the authors. 